\title{
The role of plots and building types in the morphological research of Chinese traditional village tissues
}

\author{
Pengyu Guo, Wowo Ding* \\ School of Architecture \& Urban Planning, Nanjing University, Nanjing, Jiangsu, China \\ *(corresponding author) \\ E-mail:dww@nju.edu.cn
}

\begin{abstract}
In Chinese traditional village, the morphological transformation of village tissue was embedded in the changing of co-existing morphological elements that recorded the geographical evidence of social structural changing from traditional private ownership economy to rural collective economy. The interactive relationships of individual plots and building types require investigation in detail as theoretical praxis in the morphological research of village. Several questions need to be clarified in relation to plots changing and new plot setting: how the building type transited when the plots size reducing or extending and what is the plot extending rules? What is the principle of plots re-dividing and whether the plot can be re-divide when the building belong to its kept unchanging? Is that plot limits building types or building type decides the size of the plot? Focusing on a village in north of China this paper will investigate how the morphological elements worked and acted during the village transformation, based on the field survey, residential recordings and village maps in several period. Our results will indicate that the role of the plots and building types were different between villages and urban, which were interacted each other differently. The co-relation of plots and building types of the village are developed.
\end{abstract}

Keywords: Parent plots, sub-divided plots, building types, village tissues

\section{Introduction}

Urban morphology reflected the social development. As the research object, the morphological elements are highly sensitive to socio-cultural forces opening over time and are defined by three fundamental physical elements: buildings, plots and streets (Moudon 1994,1997). A generic structure of urban form, the hierarchy of morphological elements, has been studied in relation to the M. R. G. Conzen, Gianfranco Caniggia and Gian Luigi Maffei (Kropf, 2014). Morphological elements in different levels of resolution are a synthesis of all components, which contribute to the concept of urban tissue (Kropf, 1996). For Conzen, individual plots are the fundamental unit of analysis (Kai Gu, 2014) whereas the existed buildings and its mechanism are the research base of Caniggia. Form different approach, they aim to understand the physical changing of urban form in a complementary way. The analysis in Alnwick from M.R.G.Conzen provided an evolutionary approach to tracing existing forms back to the underlying formative processes and interpreting them accordingly (M.R.G.Conzen, 1961). Originated from Saverio Muratori and based on processstructured reality, Caniggia $G$ developed the methodology in which examining past building is the "historical-type" or "process classification" through the extracting the laws of behavior, formation and mutation of manmade structure on various scales of built environment (Caniggia G, 2001). Conzen focus on town plan analysis that require 

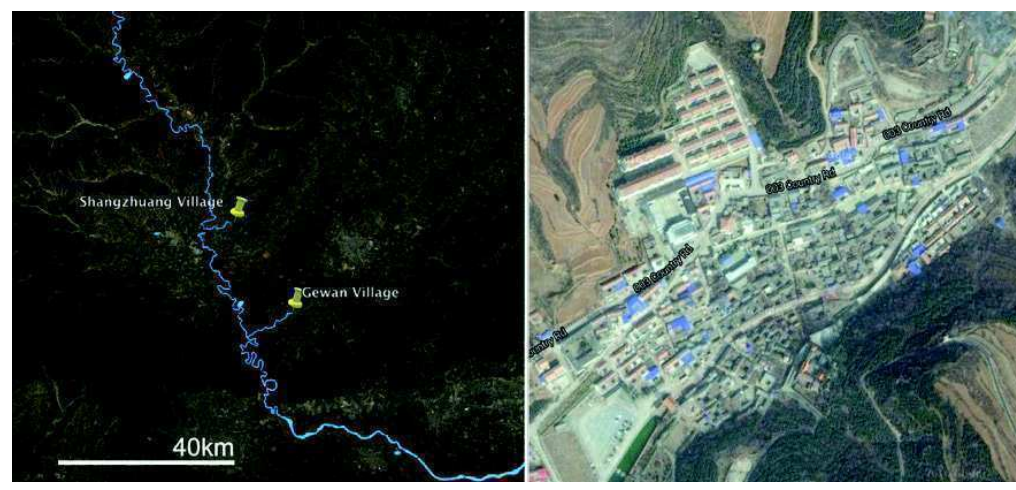

Figure 1.

Satellite image of Shangzhuang Village (left), Gewan village (middle) and location (right).

historical map in the scale of $1 / 2500$ contain the information of streets, plots and blockplan, whereas Caniggia aimed to interpret individual buildings and its mechanism by which the form created in one morphological period are succeeded by those created in the next, that require building information over times. To understand village form suggests the research of interactive relation of morphological elements that reflect the mode of production and land system. Morphological elements in Chinese village also contain building types, plots and streets, each of which present its importance in history. Originated from living experience, clear and stable building type construct the original village form and continue adjusting to accommodate the changing family, accompanying by plots sub-dividing and extending. Conversely, plots regulation played a crucial role in village planning that influenced village form after 1980s. This contrast requires a synthesis method to interpret village morphology by employ the approaches of British School and Italia School. It is the foundation to clarify the terminology in research context since the concept of plots has no clear consensus (Kropf, 1997). In traditional area, plots were originally defined by courtyard building types with the same access and shared yard, namely, plots present both space control and ownership. Through property redistribution, sub-divided plots gain its ownership boundary inside parent plots that continued existing in order to provide the common spatial control, a shared yard and access to subdivide plot. Transformation of morphological elements records the geographical evidence of social changing: family structure changed from composite family and lineal family in traditional private economic system to nuclear family in collective economic system. Together with economic system and its corresponding family structure, physical elements contribute a relatively stable structure that may fix itself or transform into another structure by some internal adjusting. As theoretical praxis, this paper will go through the internal relationships of individual plots and building types based on morphological process of village through Shangzhuang village complemented by Gewan village in relation to different types of transformation. The different morphological interaction comparing with urban context was developed and further indicates a structural relation between village form, social economy and family structure.

\section{Case and research condition}

Village, building types and plot changing

The selected cases suppose to have the character to span the different historical period and contain general building types that continued transforming in process. Originated from Qing Dynasty, Shangzhuang village located in North of China by Qin River where there were several building types. However, Shangzhuang Village had the limitation related to transformation of traditional building types before 1949, hence Gewan Village, pertaining to the same culture circle, complements this morphological changing (Figure 1). The research of Shangzhuang Village was based on 
official documents after 1949 and the analysis of Gewan Village relied on family document contains inscription in physical structure and family documents before 1949 .

Around Qin River, reflected the changing of family structure there were several chronological building types, traditional courtyard houses, variant courtyard houses and new building types including semi-detached houses and multi-storey apartments ${ }^{1}$, which characterized 3 periods marked by private economic system before 1949, from land reform in 1949 to economic reform till 2000s and urbanization after 2000s (Guo, 2017).

Before 1949, under private economic system, composite family contains several nuclear families cultivating traditional courtyard building type, but family separation only happened by the elder's passing away. Courtyard building types adjust its composition geometrically in the way of typological character contains "Jian", buildings, basic courtyard and composite courtyard so as to adapt family changing (Guo, 2017). The basic living module is "Jian" that measured and composed buildings in one or three Jian. Building with three Jian was a standard unit for a nuclear family and building with one "Jian" played as auxiliary unit to serve 3 Jian buildings. Buildings has the capacity to be basic courtyard to meet the requirements of composite family who's expanding led the composite courtyard. Plots of traditional courtyard house were recognized by courtyardplan.

In 1949, land reform in Chinese village give rise to the redistribution of property according to family scale, that triggered the re-dividing of courtyard house in name of communism. From 1949 to 70s, new building was not built because of relatively poor economy (Jilin Wang, 2001). From 1949 to 1962, plots can be traded as private property. Since 1962, the ownership of plots belonged to collective production team and the right of use belonged to village residents. However, residents had the ownership for buildings whose trading is free and the right of using of plots followed the changing of building. Around middle of 1970s, economic reform brought the booming of productive force and plenty of building was built (Jilin Wang, 2001). Family structure generally changed form composite/linear family to nuclear family trigged by popularizing family separation (Wang Y, 2000,2007,2008). Another property redistribution appeared for the separation of family by the marriage of next generation. Traditional building types continued serving this social transformation. In 1982, because of a national building and plot policy, new plot was strictly controlled. When new plots required an application with general decreased given area around 1982, 1986, different variant types emerged in new territory through keeping the courtyard pattern and Jian but adjusting building composition. For variant building types served for a nuclear family, the north building continue existed and contained 5 to 8 Jian whereas the west and east building became serve part and the south building commonly disappeared. In between traditional type and variants, both of courtyards was the spatial center but the social center changed form courtyard to north building.

Around 2000, influenced by modern living mode in urbanization and continuing limitation of land resource, new plots was given smaller area adapted by imported building types, semidetached houses and multi-rise apartments without the character of courtyard houses. Multi-rise apartment lost plot and gained a collective plot and semi-detached houses still had plot.

Historical map provide the foundation for the village transformation. Originally, parent plots both present spatial unit and property unit defined by building-plan, a complete courtyard house accommodating one family. Plots sub-dividing suggest the separation of ownership but continually shared space access in parent plots. In the residential recording of 1992, parent plots was given a term of Zong di with registration number because of the shared courtyard. Shangzhuang Village map in 1992 and 2006 in the scale of $1 / 1000$ are the precondition of historical map. Other historical map in former time including building types map and plot map was reconstructed through residential recording in 1992, residential recording in 1949 and other historic researches on this study case (Figure 2) (Guo, 2017).

The changing of population, family 

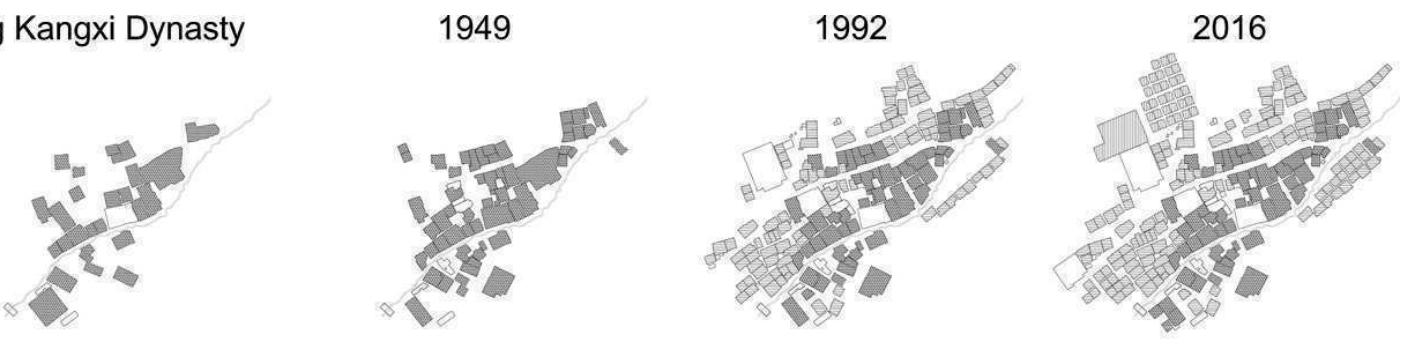

Buildings map
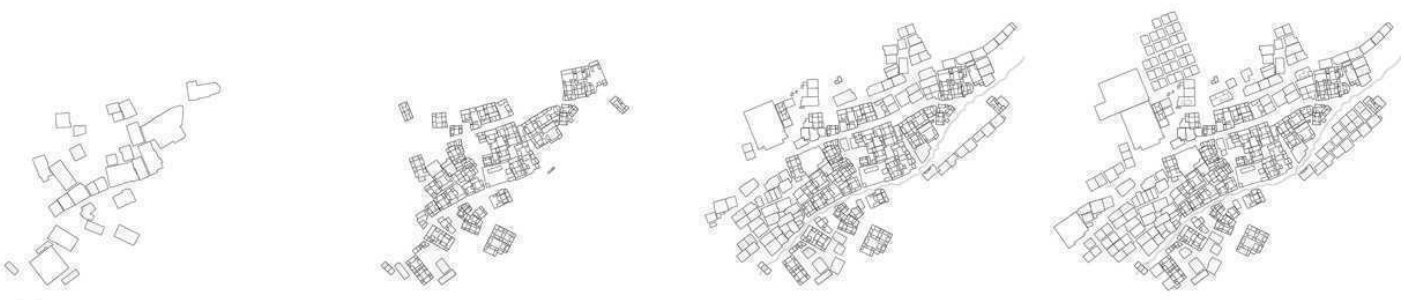

Ownerships map
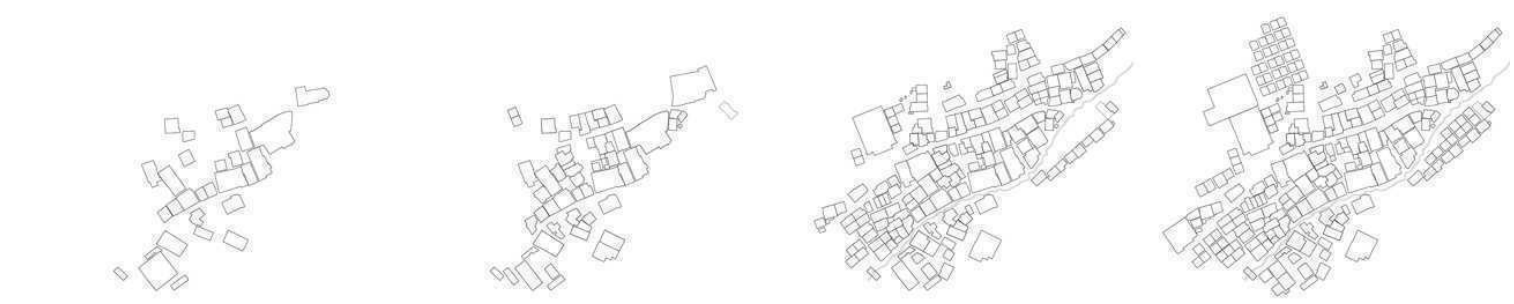

Parent plots map

Traditional building types

Variant building types

Imported new types

Plots

$050 \mathrm{~m} \quad 100 \mathrm{~m}$

Figure 2.

Previous study of transformation of Shangzhung Village in relation to building type and parent plots.

quantities, parent plots quantities and plots quantities of ownership was showed according to historical map and Historical Records of Shangzhuang village. Quantities of plots ownership, population and family quantities had stable increasing since 1949. However the quantities of parent plots (Zong di) keep unchanging because of there were no new construction before 1980. It suggested the role of family changing that might not changed the quantities of building or building types through new parent plot but changed plot ownership.

\section{Family documents}

Individual morphological elements were conditioned by family changing. Before 1949, the time of missing documents, family tree and certificate of family separation indicates the relationship of residents contain family number and separation time, whereas the inscription of beam structure indicated name of householder and built time, the relationships of residents and buildings. So far, the transformation of building, parent plots and plots sub-dividing can be reconstructed. After 1949, official residential information was recorded in 1949 and 1992. Residential recording in

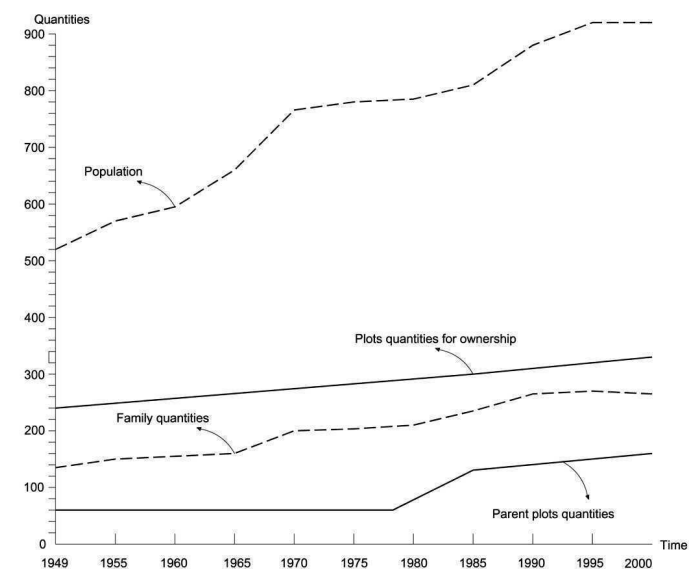

Figure 3.

Statistics of area and quantities of plots and buildings 

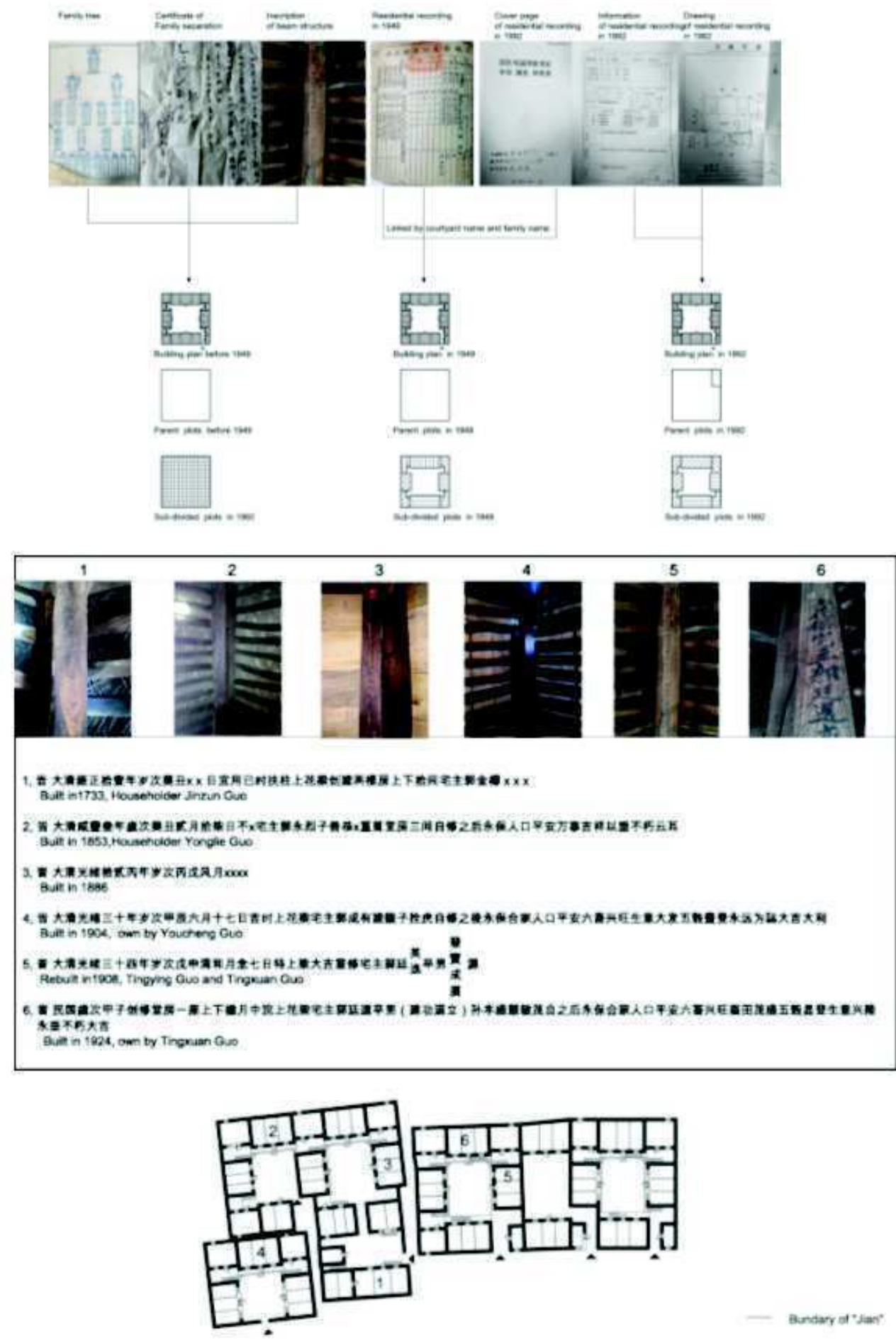

Figure 4.

a. (above) Family documents and residential recordings. From left to right: family tree, certificate of family separation, inscription of beam, residential recording of 1949, cover paper of residential recording in 1992, information page of residential recording in 1992, plot drawing page of residential recording in 1992. Each of pages project to certain part of reconstruction of individual elements

b. (center) Building inscription. Information in beam structure indicate name of original householder and built time.

c. (below) Current building plan with inscriptions in building structure. 

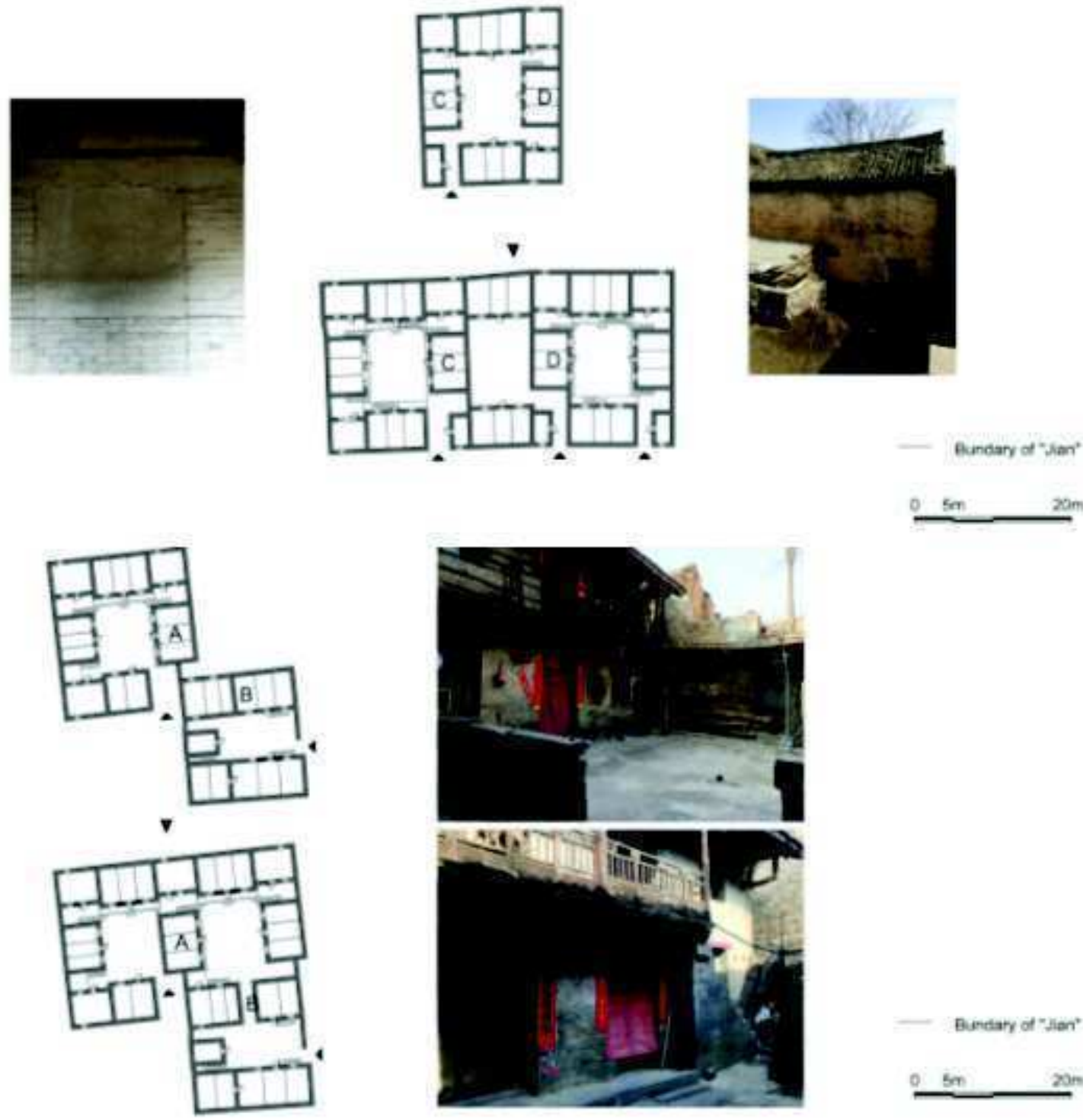

undary of "Than'

Figure 5.

a. (above) and b. (below) Construction marks indicate the compositional changing related to re-setting of entry. 1992 contains cover paper showing number of parent plot, name of householder and address, information page with ownership, area, family members and family separation certificate and plot drawing page indicating sub-divided plot and parent plot. Family was the unit of recordings and several families might share the same parent number with the same courtyard. Although residential recording in land reform of 1949 only described house name, householder, property list and border in witting without drawings. The shared same courtyard name and concept of "Jian" as basic measuring unit in between recording 1949 and 1992 linked each other that contribute to reconstruction of building and plot in $1949^{2}$. What is more, the objective properties were buildings, which defined plots, pertain to buildings. Further information in 2006 could be investigated by residential map in 2006 and field survey (Figure 4a).

In the study area of Gewan Village, conserved inscription in beam structure was belong to different buildings (Figure 4b, Figure 4c) that contribute to later reconstruction of individual morphological transformation. Considering each family occupying one courtyard, any one inscription of courtyard house can indicated relative built time and householder though some of inscription was damaged. 


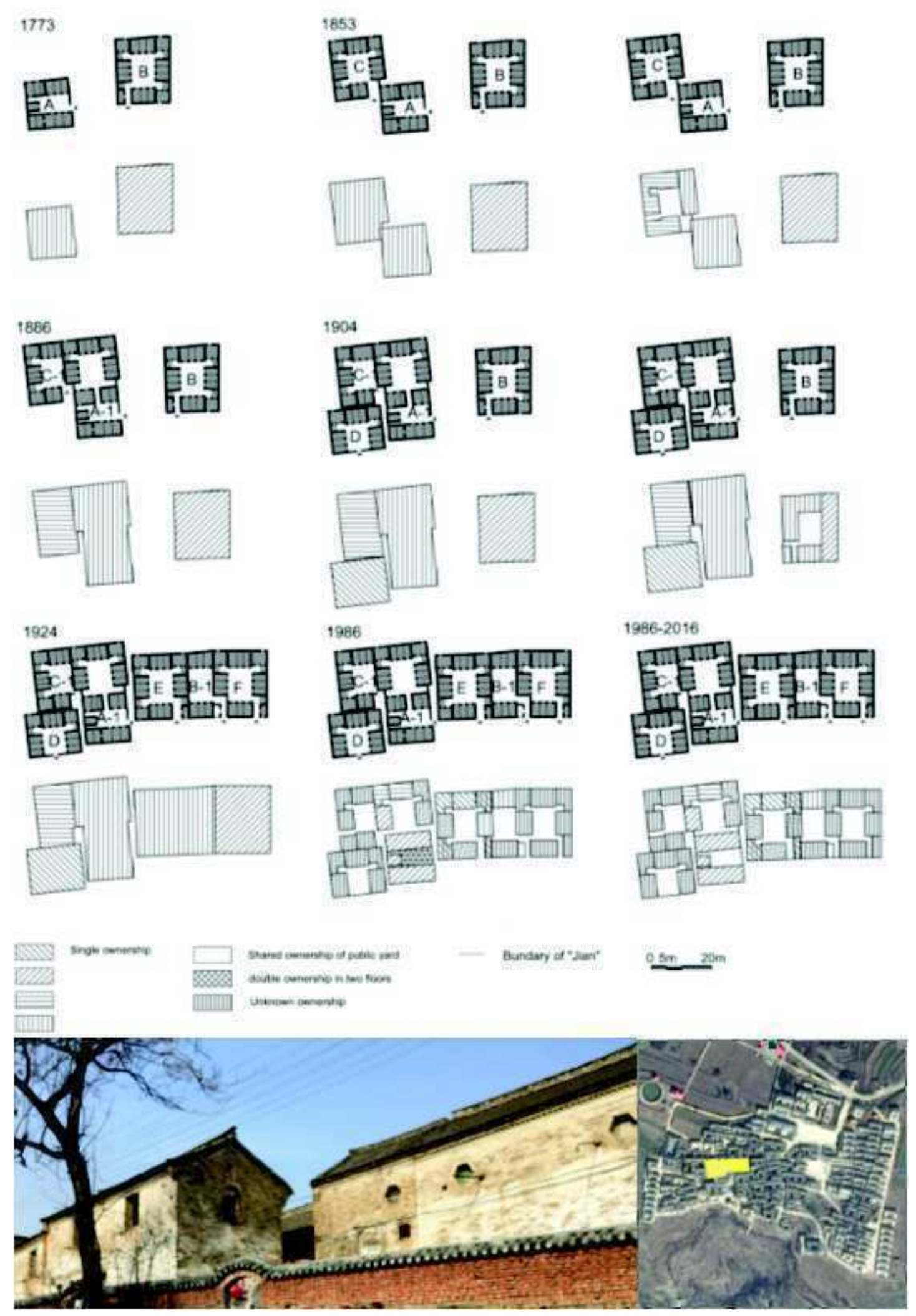

Figure 6.

Samples in Gewan Village. Current plan was constructed by field mapping and historical transformation was reconstructed by inscription in building structure, family tree, certificate of family separation and construction marks. 


\section{Physical evidence}

The historical reconstruction marks decodes the compositional transformation of building plan that operated in 2 ways, extending from a whole courtyard house and extending from part of courtyard house that suggest a former plot sub-dividing (Figure 5a, 5b).

In the process of transforming of Gewan Village, entry was cut into building B and building A changed its entry to opposite yard in order to extend to double courtyard house from complete courtyard house. After separation of parent plots, the entry of building $C$ and $D$ was changed to opposite yard so as to form another 2 courtyards house (Figure 4c).

The transformation of village form suggests a hypothesis of interaction of individual plot and building type that reflect family changing.

\section{Morphological Changing of individual elements}

According to building types, individual building plan, parent plots and sub-divided plots in transformation of Shangzhuang Village were constructed in order to reduced to several typical changing types (Appendix 1 shows a statistics of different changing types). As complementary, the process of selected block in Gewan Village also presents its individual changing of elements. Typical samples in 2 cases focus on different period.

\section{Traditional building types}

Since the lacking of official building recording before 1949, family documents and physical evidences have the capacity to recover the transformation of individual buildings and plots in Gewan Village from1773 to now (Figure 6) . $^{3}$

Since the strictly controlling of plot area for each family after 1949, almost plot extending appeared before 1949 when composite family enlarge its scale ${ }^{4}$. Based on the family ownership, it is clear that the some of extending commonly started from a standard courtyard house to composite courtyard house and some of extending approach from part of courtyard house that inversely left the shrinking plot. This extending and shrinking suggest a former plot sub-dividing though there were no evidences to support. Plots changing did not restrict building types but was conditioned by adjusting of building composition defined by variation of composite family. Extending area was based on the multiples of courtyard house and the sub-divided plots were one or several buildings. The traditional construction enables the property redistribution.

Some of sub-divided plot was restricted inside of parent plot may adjust its ownership and some of sub-divided plots without surrounding restriction lost the access to parent plot in order to set up new plot to form a irregular building type by expanding its area till other constructions or road.

Land reform in 1949 redistributes all the building property in average. Buildings measured by 3 or 1 "Jian" conditioned plots sub-dividing and building still did not changed. Around 80s, limited trading and further popularizing family separation by the changing of family structure lead to a continuing property redistribution in-between generations, which give birth to re-distribution of sub-divided plots based on buildings. However parent plots still contained sub-divided plots with shared yard and access. The sub-divide plots reserve the further changing of parent plots and building types (Figure 6).

\section{Variant building types}

Variant building types characterized period from 1980 s to 2000 when there were 2 times for new plot restriction before and after 1986 triggered the more and more smaller plots that restricted 2 Variant building types. In the property redistribution for popularizing family separation in between generations around 80 s, sub-divided plots appeared inside of the parent plot. When parent plot and building keep unchanging, sub-dividing principle here is based on the redistribution of "Jian". Building construction changed form wood construction to concrete construction. After 1986, the more decreased plot area influenced another smaller variant courtyard building type. However, family separation in generation 


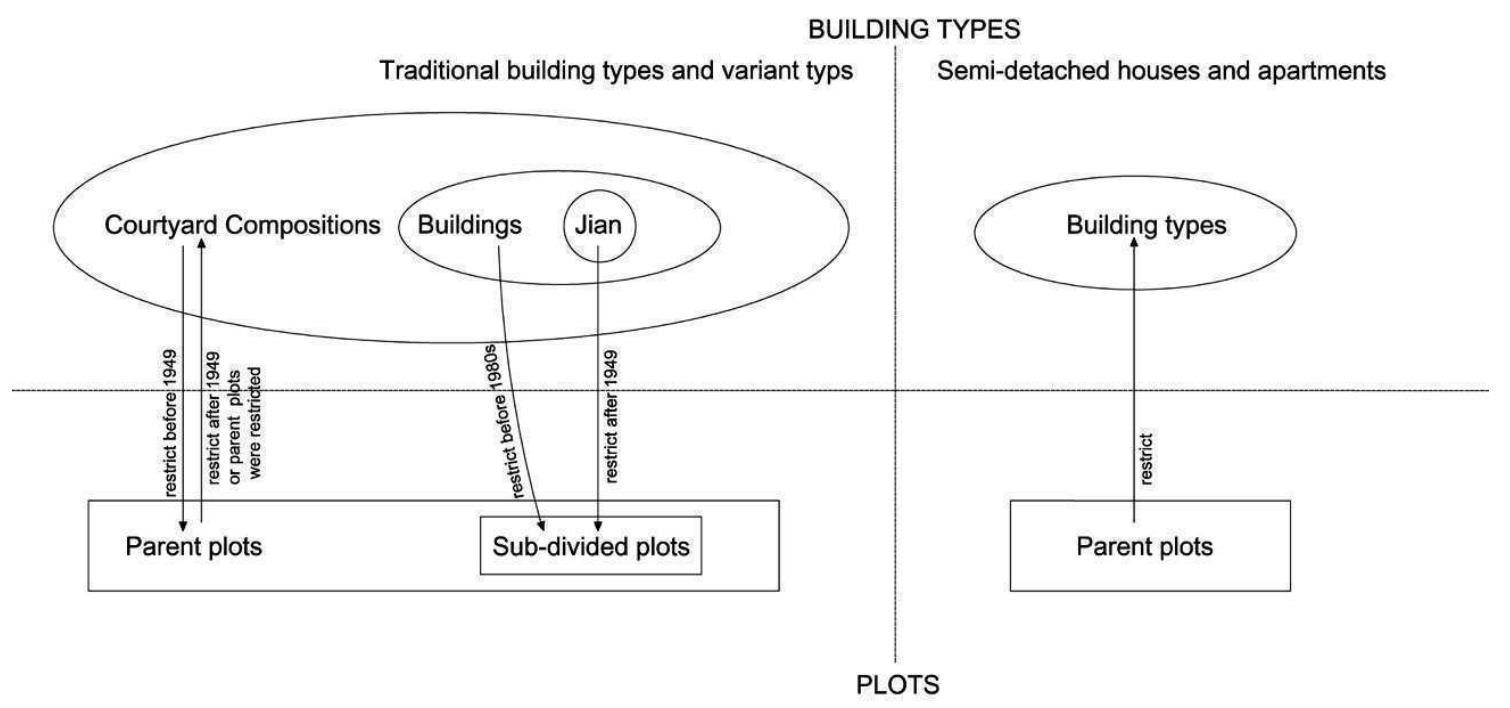

Figure 7.

Diagram of interaction of plots and building types.

did not triggered property redistribution inside this variant courtyard house because of birth control and continually increasing of house quantities. According to residential recording in 1992, the average place quantities of each family were 1.77 .

\section{Semi-detached houses and apartments}

Since the limitation of land resource, new plot area was reduced around 2000. Semi-detached housed and apartments was imported through the adaptation of new plot area. Semi-detached houses still gain its plot by one nuclear family but lost the typological character of courtyard houses that indicate the difficulty of property redistribution. Apartment lost private plot and shared a common plot by a group of family who face the same difficulty of property redistribution. So far, typology and plot situation evolve into a global modern consensus.

\section{Review}

After the investigation in detail, morphological elements in village left geographical evidence that present a changing relationship referred to the transformation of economic system and family structure. Before 1949, a stable political and production mode cultivated the composite family accommodated by a stable building type that perform its flexibility through its composition to redefine plots according to family changing. In 1949, for the political cause, land reforming under the economic system changing forced the property redistribution in the way of plot redividing that confront and restrict to another culture force, building type, because of the still stable culture pattern in a relatively poor economic context. After 1970s the changing of production mode led to the changing of family structure from composite family to nuclear family that could not fully adapt traditional building type. Irregular building types derived from traditional plots for the limited space and variant building type emerged from outer space of village in standard given plots. As a smaller courtyard house, variant building type inherited the compositional capacity in courtyard and 3 "Jian" building components of traditional building type so as to full fill the continual property redistribution by family separation in between generations popularized around $70 \mathrm{~s}$. Around $2000 \mathrm{~s}$, by the limitation of land resource and ideology of urbanization, new building type lost compositional capacity in the way of apartment and modern single house with smaller plots that led to the impossibility of plot re-dividing. 


\section{Conclusion}

In Chinese traditional village, plots changing were conditioned by building typology and also restrict building types (Figure 7). The morphological characters of traditional courtyard building type and variants contain building composition, buildings and its "Jian" components. Parent plots may continue existed only as space unit when sub-divided plot appeared inside as property and continue to extend into another courtyard. The relationship between parent plots and sub-divided plots indicated the relationship between building typology and family ownership. Semi-detached house did not have the capacity to generate sub-divide plot and apartment lost plot of individual family.

Before 1949, originated from one of parts of traditional courtyard house, the enlarging of plots were restricted by building composition, accompany the variation of composite family. The extended area was based on the multiples of courtyard house and the sub-divided plots based on buildings. In the land reforming of 1949 and later popularized family separation, plots of traditional building types were redivided based on buildings when the original building did not change. In variant courtyard house types, sub-divided plots trigged by populated family separation were conditioned the standard of "Jian". However, variant type around 2000 did not have redistribution for the continually increased quantities of houses and controlled birth rate.

Before 1949, plots defined by traditional building composition corresponding with composite family. In traditional parent plots, some of sub-divided plots restricted by surroundings cultivated an irregular type in plot extending in all built times. When family structure changing from composite family to nuclear family, variants types inherited the character of courtyard but was restricted in different compositional sequence by smaller plot. When given plots is too small to support a courtyard type, the imported model, single houses and apartments was introduced in limited plots.

When traditional building type ended around 2000s, new building type did lost the typological capacity to direct plot sub-dividing.

It is clear to see the interaction of building types and plots in this historical transformation. Considering this interrelationship, the process of typology may be understood and typomorphology may not be reduced to building typology, but a synthesis of interaction between building types and plots. The conclusion developed the concept of interaction of plots and building type contributing to understanding of village tissues.

\section{Acknowledge}

This study was financially supported by Major Program of National Natural Science Foundation of China (No.51538005).

\section{Notes}

1 Additionally, some irregular building type commonly appeared within a sub-divided plots and latter extending plot limited by surroundings.

2 For example, document of No 20515101 in recording in 1992 shared the same house name of "Courtyard of the Yans" with that recording in 1949. Recording in 1949 indicated that Yuxiang Cao and his family (6 persons) own 3 "Jian" of southern building, 3 "Jian" of eastern building and 4 "Jian" of southeastern building and his brother Tai'an Cao own 6 "Jian" of western building, 3 "Jian" of eastern building, 5 "Jian" southwest building, 1 "Jian" of northeastern building and 1 "Jian" of northwest building.

3 Courtyard A and B had been constructed in 1773. Before 1949, plots separation supposed to appear in between 1853 and 1886, 1904 and 1924 , so as to contribute to new plot extending from A to A-1 and from B to B-1, E and F.

4 Page 62, Jilin Wang(2001). Historical Records of Shangzhuang village, From 1979 to $1990,64.89 \%$ of new residential buildings surpassed the area of given plots illegally, hence the residence received fine. 


\section{References}

Caniggia G, Maffei G L. Architectural composition and building typology: interpreting basic

building[M]. Alinea Editrice, 2001.

Conzen M R G. Alnwick, Northumberlansd: a study in town-plan analysis[J]. Transactions and

Papers (Institute of British Geographers), 1960 (27): iii-122.

Tian, Y., Gu, K. and Tao, W., 2014. 'Urban Morphology', Architectural Typology and Cities in

Transition (Science Press), 2

Karl Kropf. (1996). Urban tissue and the character of towns. URBAN DESIGN International, 1(3), 247-

263.

Kropf, K., (1997), When is a plot not a plot: problems in representation and interpretation.

In unpublished paper presented to the Fourth International Seminar on Urban Form, Birmingham, England, July.

Kropf, K. (2014). 'Ambiguity in the definition of built form', Urban morphology, 18(1), 41-57.

Moudon A V. (1994) 'Getting to know the built landscape: typomorphology', Ordering space: types in

architecture and design(Van Nostrand Reinhold, New York), 289-311.

Whitehand J W R, Gu K, Conzen M P, et al. The typological process and the morphological

period: a cross-cultural assessment[J]. Environment and Planning B: Planning and Design, 2014, 41(3): 512-533.

Pengyu Guo, Wowo Ding. (2016) . A Morphological practice: Casing Shangzhuang Village in North of China, ISUF 2016 conference proceedings.

Pengyu Guo, Wowo Ding. (2017)The research of collective architecture type and village morphology:

Casing Shangzhuang Village in Yangcheng of Shanxi, Architectural Journal

Linping Xue. (2009). Ancient village of Shangzhuang[M]
Yaosheng, W. (2007). An analysis on nuclealization of chinese rural families [j]. Hn Jornal of Olaon $\mathrm{N}$

Wang, Y. (2000). Family structure in the mid and late 18 th century in china. Socialences in China.

Wang, Y. (2008). Theoretic analysis on transformation and mobility of family structure:based on historical and realistic experience of chinese rural areas. Journal of Social Sciences.

Shangzhuang Adiministration . (1992). Shangzhuang master plan in 1992

Shangzhuang Adiministration . Shangzhuang master plan in 2006

Shangzhuang Adiministration. Shangzhuang residence recording in 1992.

Shangzhuang Adiministration. (1949). Shangzhuang residence recording in 1949.

Jilin Wang(2001). Historical Records of Shangzhuang village:59-62 